\title{
Regarding the infrastructure modernization of the Arctic settlements using the example of Chokurdakh village
}

\author{
Albert Kardashevskii ${ }^{1, *}$, Anna Shishigina ${ }^{1}$, George Volkov ${ }^{1}$, and Evgeny Gribchatov ${ }^{1}$ \\ ${ }^{1}$ North and Arctic Interdisciplinary Research Division of Arctic Scientific Research Centre, Academy of Sciences of Sakha Republic, 22 \\ Kurashova st., Yakutsk, 677000, Russia
}

\begin{abstract}
The article discusses the infrastructure development of the Arctic settlements through the example of Chokurdakh village in the Allaikhovsky district of the Sakha Republic (Yakutia) which is on the basis of a project approach linked to ongoing and planned projects for the development of territories and sectors of traditional natural resource use. The results of a sociological survey and an analysis of the actual state of infrastructure and social facilities on the basis of which projects on improvement of the living conditions of the population are proposed. It includes creating a favourable economic environment and creating new lines of economic and commercial activity in the Arctic settlements, using local natural and human resources are presented in the article.
\end{abstract}

\section{Introduction}

The existing large Arctic settlements on the territory of the Sakha Republic were formed during the formation and development of the Soviet state for the implementation of priority state tasks - the study and development of the natural wealth of the Arctic, mining, border protection, the formation of transport hubs, etc. At the same time, the costs of operating the infrastructure were of secondary importance.

After the collapse of the USSR, the economic turmoil of the $90 \mathrm{~s}$ and the change in priorities for the development of the state, many city-forming enterprises went bankrupt, and there was a significant outflow of population from the North and the Arctic, which led to the closure of many industrial villages. So, according to researchers, 136.3 thousand people or $13.3 \%$ lived in the Arctic economic zone of the YASSR in 1986 and in $2017-68.5$ thousand people or $7.1 \%$ of the total number of residents of the Sakha Republic [1]. According to preliminary estimates, the population of the 13 Arctic regions of the republic as of January 1, 2019 was 67674 people, which is $7.0 \%$ of the total population of the republic [2].

The village of Chokurdakh, Allaikhovsky district, like many other Arctic villages of Yakutia, for the reasons mentioned above, fell into decay. The outflow of the population and the appearance of empty apartment buildings led to a change not only in the architectural appearance of the village, but also in the patterns of energy and heat supply. According to the data for 01.01.2020, the population of Chokurdakh was 2077 people [3].

The decrease in the population is primarily due to migration outflows associated with a sharp decrease in the quality of life in the macro-region, including the level of wages that do not compensate for the poor quality of life, the departure of the able-bodied population to Yakutsk and other areas, the reduction of jobs in the village.

\section{Results and Discussion}

\subsection{Social research}

\subsubsection{Content and directions of the survey}

In order to determine the problematic issues of the life of the population in the village of Chokurdakh, a sociological survey was conducted from 03.08.2020 to 10.09.2020. The full study involved 115 participants, including 47 men and 68 women representing different categories of respondents (age, income level, profession, etc.). The sample amounted to $5.5 \%$ of the target audience, while $90 \%$ of the surveyed residents were natives of the Allaikhovsky district. The main focus of the study was on determining the satisfaction of the population with living conditions and the current state of infrastructure and social facilities, as well as plans to change their place of residence, move to other settlements of the Sakha Republic or regions of the Russian Federation.

\subsubsection{Interpretation of results}

According to the results of the survey, $15.7 \%$ of respondents expressed their readiness to move, and the reasons for this decision were the tension in the labor market, the lack of development prospects, leisure and unsatisfactory infrastructure. These data point to the possibility of securing the population while creating

* Corresponding author: agkard@mail.ru 
acceptable living conditions and new jobs. This fact is indirectly confirmed by statistical observations, according to which the population of the village has remained stable over the past 3 years.

An important role in a sustainable population is played by $70 \%$ of respondents having their own housing in apartment buildings. $20 \%$ live in rented housing and $10 \%$ in official housing. An important indicator of the sustainability of the population of the village is the fact that $55 \%$ of respondents are married and $70 \%$ of respondents have children, which in a compartment with the presence of their own housing indicates settling. In addition, $60 \%$ of respondents classify themselves as middle-income citizens, which indicates the presence of permanent and sufficient sources of income for living in difficult Arctic conditions.

At the same time, $50 \%$ of respondents rate the living conditions in the village as satisfactory, $25.0 \%$ unsatisfactory, $20.0 \%$ - good and only $4.0 \%$ of respondents rate excellent.

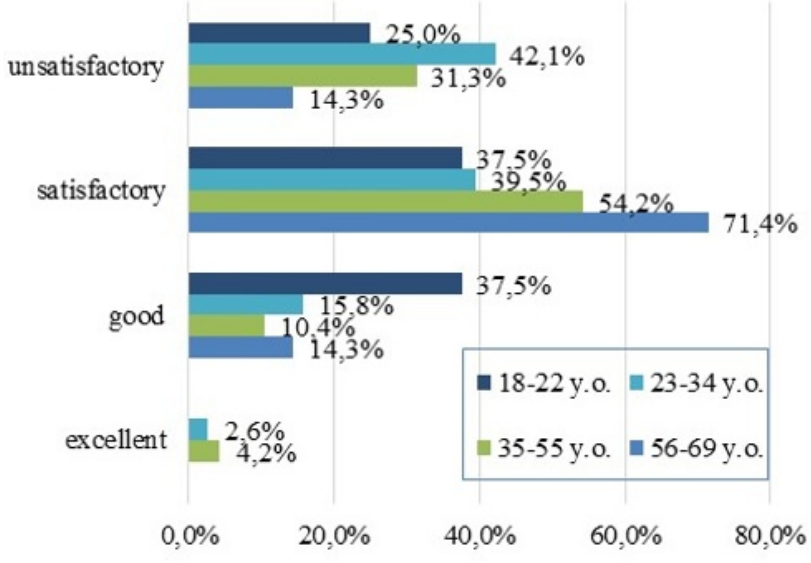

Figure 1. Satisfaction of the population of Chokurdakh with living conditions.

The population connects its future fate with the village and is interested in its development. The most pressing requests of the population according to the results of the survey are high-quality housing, the construction of roads, sidewalks, playgrounds, public spaces and accessible high-speed Internet (Figure 2).

These needs of the population are largely characteristic of all the Arctic and northern settlements of the Sakha Republic, where there is a great deterioration of real estate and engineering infrastructure, as well as practically no modern public spaces for recreation.

The improvement of public spaces for the residents of the village of Chokurdakh is primarily associated with the construction of playgrounds, street lighting, sidewalks, drainage systems and landscaping.

According to the majority of respondents, $60 \%$, the population of the village is not active in solving existing problems and the reason for this behavior is the lack of initiative and focus only on the authorities. This position indicates the lack of understanding of the population of its role in solving the pressing problems of urban economy. At the same time, as the practice of implementing federal and regional urban improvement programs shows, the population directly living in the territory and striving for positive changes initiates most successful projects. In addition, similar data were obtained by researchers from other Arctic regions with a relatively developed infrastructure, where an assessment of the current state of the urban environment is recorded as moderately unsatisfied. Estimates of residents of small cities and single-industry towns do not fundamentally differ from estimates of residents of a large city - the regional centre [4].

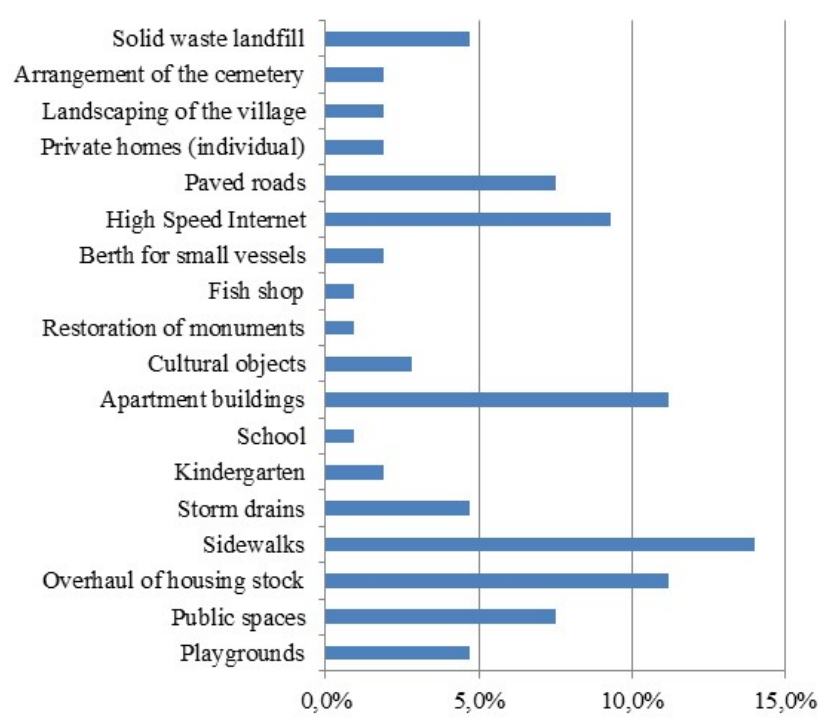

Figure 2. Priorities of the population in the development of the village of Chokurdakh.

\subsection{Projects and mechanisms for their implementation}

Analysis of modern large projects of development of resources of the Russian Arctic conducted by researchers in terms of spatial effect, which they generate, shows the presence of three main spatial effects of projects: localization effect, district effect, inter-corporate effect [5].

In the context of an acute budget deficit and an unstable economic situation in the energy market, it is a very difficult task to predict the development of remote Arctic and northern territories. The main framework for the implementation of the state policy of the Russian Federation for the development of the Arctic zone is the state programs.

The organization of management processes on the basis of strategic planning and the tasks, goals and priorities formed in the planning process involves the implementation of projects and programs for the development of territories. This takes into account financing from various sources: both from budgets of different levels, and using the funds of departments and private investors, as well as the option of public-private partnership [6].

A key advantage of the village of Chokurdakh, as well as other Arctic settlements of the Republic of Sakha 
(Yakutia), is the opportunity to participate in the implementation of special tools to ensure the socioeconomic development of the Arctic. It includes the state program of the Russian Federation "Socio-economic development of the Arctic zone of Russia until 2025", the Strategy for the socio-economic development of the Arctic zone of the Republic of Sakha (Yakutia) for the period until 2035 (Decree of the Head of the Republic of Sakha (Yakutia) dated 14.08.2020, No. 1377).

In these conditions, based on the current state of the infrastructure and the needs of the population of the village, development projects were formulated in relation to the state and regional programs being implemented.

\subsubsection{Renovation of the housing stock in Chokurdakh}

The project is aimed at designing and building new residential and social buildings, improvement facilities and recreation zones, bringing to a satisfactory state the level of improvement of the courtyard and public areas of the village.

The main mechanisms for the implementation of this project are consistent and mutually complementary state and municipal programs and investment projects of economic entities implemented on the territory of the Allaikhovsky district of Yakutia.

Currently, the following programs are being implemented in the district:

1. State program of the Republic of Sakha (Yakutia) "Formation of a modern urban environment in the territory of the Republic of Sakha (Yakutia) for 20202024 years". At the initial stage of the program implementation, the master plan is developed and the urban planning documents of the village of Chokurdakh are updated. The size of financing of the first stage is 1.8 million rubles.

2. Regional program for the overhaul of common property in apartment buildings in the village of Chokurdakh. The planned volume of investments within the framework of the regional program of overhaul of common property in apartment buildings in 2020-2035 amounts to 173.755 million rubles.

3. The republican targeted program "Resettlement of citizens from the emergency housing stock 2019-2025", which includes 27 apartment buildings in the village of Chokurdakh or 311 residential premises with a total area of 15101.31 sq. m. Under this program, the improvement of housing conditions will affect 800 residents, which is $38.7 \%$ of the population of the village. The amount of financial resources for 2019-2025 provided for the implementation of the program in the village of Chokurdakh is 1747.765 million rubles (in 2019 prices).

The marginal cost of construction (acquisition) of 1 square meters of the total area of housing under the resettlement program for the conditions of the village of Chokurdakh is: stone - 118870 rubles, quick-to-produce - 91131 rubles, wooden - 79258 rubles. According to the Ministry of Construction and Housing and Communal Services of the Russian Federation (Order
No. 351/pr "On the standard cost of one square meter of the total residential area for the second half of 2020 and indicators of the average market value of one square meter of the total residential area for the constituent entities of the Russian Federation for the third quarter of 2020 " dated 29.06.2020) the average market value of 1 sq. $m$ of the total housing area in the Sakha Republic for the 3rd quarter of 2020 is 83,191 rubles. Accordingly, the increase in construction costs for the conditions of the village of Chokurdakh, taking into account the complex transport scheme and the limited construction season, according to approved standards, is $42.8 \%$ compared to the average market value of 1 sq. $\mathrm{m}$ of the total housing area in Sakha Republic.

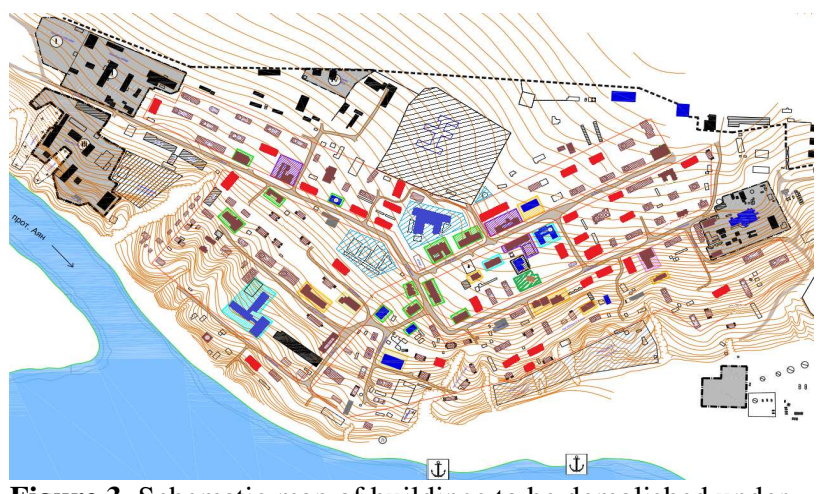

Figure 3. Schematic map of buildings to be demolished under the program "Resettlement of citizens from the emergency housing stock 2019-2025".

The real cost of building residential buildings in a stone version in the village of Chokurdakh, subject to the delivery of materials from Yakutsk, will be within 125132 thousand rubles per sq. $\mathrm{m}$. That does not meet the requirements of the program, and residents of inaccessible Arctic areas find themselves in limited conditions for choosing the structural part of future housing. For them the most durable and reliable type of buildings becomes practically inaccessible - stone buildings on a reinforced concrete foundation.

Uneven deployment of production facilities for the production of construction materials in the territory of the Sakha Republic significantly increases the cost of construction due to high tariffs for transport services [7].

A significant increase in the cost of building stone buildings is due to the high transport costs for the delivery of the initial components of the concrete mixture - cement, crushed stone, sand. Moreover, the largest size is occupied by mineral fillers crushed stone and sand. The transportation scheme for the delivery of materials and the absence of locally developed quarries of building materials (ASG, crushed stone, construction sand, etc.) significantly increases the cost of construction, especially stone buildings on reinforced concrete foundations of various types tape, slab, pile. In addition, for the construction of intra-quarter roads and sidewalks, engineering communications and improvement facilities (children's playgrounds and sports grounds), OPI such as river sand, sand and gravel mixture, limestone or gravel are used in large volumes. 
The lack of accessible developed deposits of building stone, sand, clay, etc. in the Arctic regions forces many developers to look for alternative solutions to stone construction. In recent years, in the Arctic regions, technologies of frame house building have been actively introduced using light steel thin-walled structures and mineral wool insulators. But the text of annex 2 of the republican targeted program "Relocation of citizens from the emergency housing stock for 2019-2025" explicitly states that "It is not recommended to build houses and purchase housing in houses made of light steel thinwalled structures (LSTK), SIP panels, metal sandwich panels..."

The problem of the lack of local building materials in the conditions of inaccessible territories of the North and the Arctic is limiting not only in housing construction, but also in the improvement of the yard areas of settlements, the construction of paved roads and bridge crossings.

The optimal solution to this problem for the conditions of the village of Chokurdakh is the organization of small production of building materials based on local mineral raw materials with orientation and interaction with existing and planned state and municipal programs for the development of territories.

The implementation of this project will be facilitated by the existing system of training specialists in the field of construction materials science with extensive practical experience at the North-Eastern Federal University [8].

\subsubsection{Small production of building materials and products}

Developed deposits of construction raw materials are mainly grouped in the central, southern and western part of Yakutia [9].

The prerequisites for organizing the production of building materials are the Hara-Tas igneous rock (andesite-basalt) deposits located $17 \mathrm{~km}$ east of Chokurdakh, suitable for the production of building materials. The forecast reserves of raw materials according to the estimates of the State Committee of the Republic of Sakha (Yakutia) for geology and subsoil use are 2065 thousand $\mathrm{m}^{3}$, while the average annual production levels can reach 60 thousand $\mathrm{m}^{3}$. In addition, in the area of Oyotung $(26 \mathrm{~km}$ from the village of Chokurdakh) has reserves of building stone with certain book reserves of 13 thousand $\mathrm{m}^{3}$ suitable for crushed stone production.

Sources of raw materials for the production of building materials can be deposits in the nearest areas along the Indigirka riverbed. According to the Register of the existing licenses for subsoil use on subsoil plots of local value on the navigation channel of the Indigirka River in Abyysky district the extraction of construction sand and sand-gravel mix by large enterprises of the region-state enterprise "Road of the Arctic" and Public Joint-Stock "Lena River United Shipping Company" is conducted.

Difficult conditions in the development of existing deposits of common minerals require a large amount of investment and such projects cannot be carried out by small enterprises, especially if they are engaged in the implementation of short single projects, such as the construction of low-rise apartment buildings or the improvement of a limited area (sidewalks, playgrounds, intra-quarter roads, etc.).

An integrated approach to solving issues of landscaping and housing construction involves attracting and coordinating the work of many multi-directional enterprises and institutions, which significantly complicates the work process and increases risks. The most suitable option for the organization of work on the improvement of the village from the point of view of management and cost optimization is the creation of a joint venture within the framework of a municipalprivate partnership, whose functions will be transferred to work on projects for the improvement of the village and housing construction.

Currently, the Municipal Unitary Enterprise Industrial Transport and Construction Complex "Polyarnik" (Municipal Unitary Enterprise PTSK "Polyarnik") operates on the territory of Chokurdakh, on the basis of which a joint venture can be organized with the involvement of interested economic entities. Directly producing building materials in the Allaikhovsky district belongs to the production cooperative of the nomadic ancestral community "Allaikha" (PC KRO "Allaikha"). This organization has established the production of insulation from polystyrene foam in the form of boards of various sizes. Today, KRO Allaikha PC has the necessary production areas and equipment to organize the production of other types of construction materials.

In accordance with the estimated calculation in the next 5 years for the implementation of plans for the demolition of emergency and the construction of new housing with a resettlement program from the emergency housing stock for 2019-2025, the need only for crushed stone for the arrangement of vertical planning, reinforced concrete foundations and public roads of local importance will be more than 42 thousand $\mathrm{m}^{3}$.

The delivery of material in such volumes increases the cost of construction products by $62-66 \%$, which ultimately increases the estimated cost of finished housing in the stone version.

The purpose of the proposed project is to develop new areas of economic activity, as well as optimize costs for the construction of residential and public buildings in the village of Chokurdakh. The main mechanism for implementing the project is public-private partnership with the creation of a consortium or cluster of enterprises operating in the construction sector.

The initial stages of the project implementation include the following works: justification, registration, preparation of permits (licenses) and development of a field of common minerals in the territory of the Allaikhovsky district.

The next stage of the project implementation is the organization of small production for the manufacture of construction rubble, concrete blocks, paving tiles and curb stones. The project provides for the development of a quarry of building stone and the organization of its 
processing in accordance with the requirements of GOST 8267-93 "Crushed stone and gravel from dense rocks for construction work. Specifications" with a total capacity of 10 thousand $\mathrm{m}^{3}$ per year.

On the basis of the obtained crushed stone, it is proposed to organize the production of concrete wall and partition stones according to GOST 6133-99 "Concrete wall stones. Specification" with a total capacity of 2100 $\mathrm{m} 3$ per year and workshops for the production of mortars and concrete in accordance with the requirements of GOST 7473-2010 "Concrete mixtures. Specification" with total capacity of $20 \mathrm{~m}^{3} / \mathrm{h}$.

The project provides for the modernization of the existing PK KRO "Allaikha" workshop for the production of polystyrene foam to increase the size and assortment of products. After the modernization of the production line, the following types of products will be additionally produced: polystyrene foam shells for utilities and tanks, bulk insulation in the form of pellets, extruded polystyrene foam for road construction, inserts for heat-efficient three-layer wall blocks.

The implementation of the project is planned in stages with synchronization with resettlement programs from the emergency housing stock, the formation of a modern urban environment and the overhaul of apartment buildings for 2020-2025. The total projected amount of financing is 38.7 million rubles.

\section{Conclusion}

The implementation of interconnected projects to renovate the housing stock and organize the production of building materials in the village of Chokurdakh will not only create additional jobs, increase the income part of the municipality's budget, but also provide a qualitative jump in the diversification of the region's economy and improve living conditions.

The total amount of investments envisaged for the implementation of all projects from the federal, regional and municipal budgets and funds of economic entities will amount to about 2 billion rubles. This, of course, is the largest in the post-Soviet history of the region and a unique chance for the Arctic settlement to change the existing situation and transition to sustainable development of the territory.

The implementation of these projects will:

- ensure the transition to a qualitatively new level of construction of housing, administrative buildings and public spaces, transform the architectural appearance of the village and create modern infrastructure to ensure quality housing, work and recreation;

- modernize the engineering equipment of buildings and improve their energy efficiency;

- create additional (seasonal) jobs for residents of the village during the improvement of territories, construction and repair of buildings (estimated the need for seasonal labor personnel is determined at 25-30 people (handyman, mason assistant, painter, carpenter, road worker, welder, etc.) annually during the construction season (April-October).
In general, the sustainable development of Arctic territories without the creation of high-quality social and housing infrastructure is impossible [10]. Therefore, new types of production that contribute to the development of the region should become priority measures on the path to sustainable development of the village of Chokurdakh along with the development of traditional industries.

\section{References}

1. I. Nikolaeva, S. Pavlova, Innovation and Investment 1, 111-114 (2018)

2. E. Danilova, Innovation and Investment 12, 260-265 (2020)

3. Territorial body of the Federal State Statistics Service for the Republic of Sakha (Yakutia), Retrieved from: https://sakha.gks.ru/folder/32348

4. O. Russova, T. Smak, I. Tarasov, Arctic and North 41, 236-247 (2020)

5. A. Pilyasov, E. Putilova, Arctic and North 38, 21-43 (2020)

6. I. Bachurinskaya, Bulletin of Altai academy of economics and law 12-3, 5-12 (2019)

7. O. Burenina, A. Andreeva, M. Savvinova, INNOVATIONS IN SCIENCE 5 (66), 69-73 (2017)

8. A. Mestnikov, S. Semenov, D. Vasileva, Fundamental research 12-1, 80-84 (2017)

9. Federal State Budgetary Enterprise "A.P. Karpinsky Russian Geological Research Institute" Retrieved from: https://vsegei.ru/ru/info/gisatlas/dvfo/yakutia/

10. T. Ediseeva, Journal of Economy and business 5-1 (63), 173-176 (2020) 